\title{
Processing of Silicon Carbide-Mullite-Alumina Nanocomposites
}

Yoshio Sakka ${ }^{\star}$

National Research Institute for Metals, 2-1, Sengen-1, Tsukuba, Ibaraki 305, Japan

Donald D. Bidinger* and Ilhan A. Aksay ${ }^{\star}$

Department of Chemical Engineering and Princeton Materials Institute, Princeton University, Princeton, New Jersey $08544-5263$

\begin{abstract}
Nanocomposite materials in the form of nanometer-sized second-phase particles dispersed in a ceramic matrix have been shown to display enhanced mechanical properties. In spite of this potential, processing methodologies to produce these nanocomposites are not well established. In this paper, we describe a new method for processing SiC-mullite$\mathrm{Al}_{2} \mathrm{O}_{3}$ nanocomposites by the reaction sintering of green compacts prepared by colloidal consolidation of a mixture of $\mathrm{SiC}$ and $\mathrm{Al}_{2} \mathrm{O}_{3}$ powders. In this method, the surface of the $\mathrm{SiC}$ particles was first oxidized to produce silicon oxide and to reduce the core of the $\mathrm{SiC}$ particles to nanometer size. Next, the surface silicon oxide was reacted with alumina to produce mullite. This process results in particles with two kinds of morphologies: nanometer-sized SiC particles that are distributed in the mullite phase and mullite whiskers in the $\mathrm{SiC}$ phase. Both particle types are immersed in an $\mathrm{Al}_{2} \mathrm{O}_{3}$ matrix.
\end{abstract}

\section{Introduction}

C ERAMIC-MATRIX nanocomposites have been receiving increasing attention largely due to their significantly enhanced mechanical properties, low-temperature densification, machinability, and superplastic behavior. ${ }^{1-3}$ For instance, in the pioneering studies of Niihara and his colleagues, fracture strengths as high as $1.5 \mathrm{GPa}$ and toughnesses as high as 7.5 $\mathrm{MPa} \cdot \mathrm{m}^{1 / 2}$ have been reported in systems where nanometer-sized $\mathrm{SiC}$ was dispersed in $\mathrm{Al}_{2} \mathrm{O}_{3}, \mathrm{MgO}, \mathrm{Si}_{3} \mathrm{~N}_{4}$, and mullite matrices. $^{3,4}$ Niihara classified nanocomposites into two general categories. ${ }^{3}$ One category consists of composites of only nanometer-sized grains. The other consists of composites where nanosized particles are distributed within the intra- and/or intergrain regions of micrometer-sized grains. The main advantage in using nanocomposites of the first category is that they can be shaped by superplastic deformation, whereas the main advantage of the nanocomposites of the second category is their enhanced high-temperature stability against grain coarsening. In this paper, we deal with the processing of the second type of nanocomposite with a novel reaction sintering method.

Nanocomposites produced by Niihara's group have been formed mainly by using composite powders mixed on the nanometer scale by conventional milling of micrometer-sized powders. Although the mechanisms of size reduction to nanometer scale and the entrapment of particles within each other are not clearly understood, this conventional milling approach has certainly been effective in processing nanocomposites with unique

M. Sacks-contributing editor

Manuscript No. 194576. Received May 12, 1993; approved March 23, 1994

Supported by the U.S. Air Force Office of Scientific Research under Grant No. Supported by the U.S. A
AFOSR-F49620-93-1-0259.

${ }^{\star}$ Member, American Ceramic Society. properties despite the fact that milling of powders generally results in contamination or reproducibility problems. Alternatively, chemical vapor deposition (CVD) has also been successfully used to process similar nanocomposites. ${ }^{3}$ However, as stated by Niihara, ${ }^{3}$ the use of CVD to fabricate large and complex-shape components is not suitable for mass production.

We propose the use of reaction sintering as a more economical and reliable method for producing nanocomposites. In this study, we chose the $\mathrm{SiC}-$ mullite $-\mathrm{Al}_{2} \mathrm{O}_{3}$ system because it has been shown that $\mathrm{SiC}-$ mullite, $\mathrm{SiC}-\mathrm{Al}_{2} \mathrm{O}_{3}$, and mullite- $\mathrm{SiC}$ systems have excellent mechanical properties. ${ }^{3-6}$ Our procedure consists of the three steps shown in Fig. 1. ${ }^{7}$ First, we consolidated micrometer-sized $\mathrm{SiC}$ and $\mathrm{Al}_{2} \mathrm{O}_{3}$ powders homogeneously through colloidal consolidation (slip casting), which is known to be an excellent processing route for improved mechanical behavior. ${ }^{8,9}$ Second, partial oxidation treatment was conducted to oxidize the surface of the $\mathrm{SiC}$ particles to $\mathrm{SiO}_{2}$ and thus to reduce the size of the $\mathrm{SiC}$ particles to nanometer size. Finally, we reacted the surface oxide and $\mathrm{Al}_{2} \mathrm{O}_{3}$ to produce mullite. As we illustrate in the following sections, the advantages of this method are that (1) the reduction of the inclusion phase to nanoscale can be achieved without milling and (2) because of a volume increase during reaction sintering, the sintering shrinkage is low.

\section{Experimental Procedure}

The $\alpha-\mathrm{Al}_{2} \mathrm{O}_{3}$ powder used in this study was Sumitomo Chemical's (AKP-50) high-purity alumina ( $\geq 99.995 \%)$ with a mean particle diameter of $0.21 \mu \mathrm{m}$ and a specific surface area of $9.5 \mathrm{~m}^{2} / \mathrm{g}$. Two types of $\beta$-SiC powders were used: Superior Graphite's HSC059 containing C (0.85 wt\%), Si (0.03), N $(0.21)$, and $\mathrm{O}(0.80)$ as major impurities, and Mitsui Toatsu's MSC-20 containing $\mathrm{SiO}_{2}(0.11 \mathrm{wt} \%)$ as a major impurity. Figure 2 shows TEM photographs of the two powders. Superior Graphite's powder is relatively coarse (indicated as $\mathrm{SiC}(\mathrm{C})$ ) with a wide particle size distribution, a mean particle diameter of $0.56 \mu \mathrm{m}$, and a specific surface area of $15.0 \mathrm{~m}^{2} / \mathrm{g}$. Mitsui Toatsu's powder is finer (indicated as $\mathrm{SiC}(\mathrm{F})$ ) with a narrow particle size distribution, a mean particle diameter of $0.15 \mu \mathrm{m}$, and a specific surface area of $21.3 \mathrm{~m}^{2} / \mathrm{g}$.

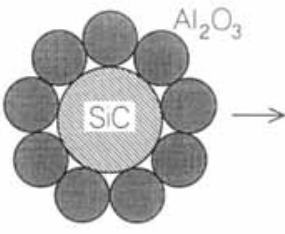

Consolidation

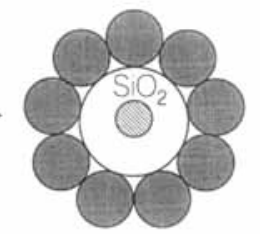

Oxidation
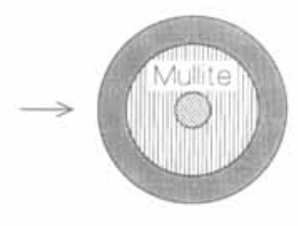

Reaction Sintering
Fig. 1. Schematic illustration of the process steps used to produce nanocomposites by reaction sintering. 

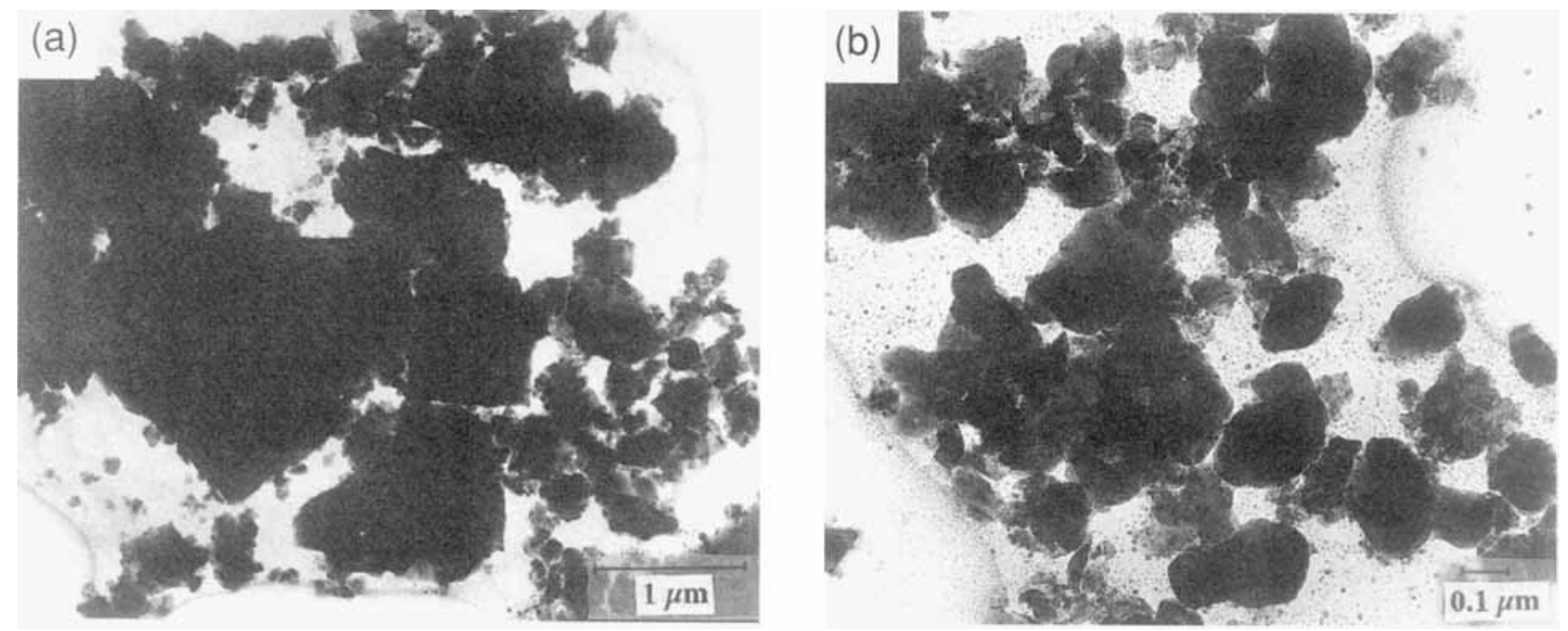

Fig. 2. TEM photographs of (a) $\mathrm{SiC}(\mathrm{C})$ and (b) $\mathrm{SiC}(\mathrm{F})$ powders.

The zeta potential of the two $\mathrm{SiC}$ powders in suspension was obtained by the Smoluchowski equation ${ }^{10}$ from the electrophoretic mobility (Otsuka Electronics ELS-800 and Bel Japan Zetasizer 4) determined on diluted suspensions containing $0.01 M$ $\mathrm{NaCl}$ (or $0.01 \mathrm{M} \mathrm{KCl}$ ) to control ionic strength. The $\mathrm{pH}$ was adjusted using $\mathrm{NaOH}$ (or $\mathrm{KOH}$ ) and $\mathrm{HCl}$.

Stable colloidal suspensions with a solid content of $45 \mathrm{vol} \%$ were prepared electrosterically in distilled water with an $\mathrm{NH}_{4}$ salt of poly(methacrylic acid) (PMAA, Darvan C) at $\mathrm{pH} 10$ as described in the next section. $\mathrm{NH}_{4} \mathrm{OH}$ was used to adjust the pH. After ultrasonic vibration (Sonic Materials Vibracell 600W Unit, Danbury, CT) was applied for $10 \mathrm{~min}$ to facilitate the dispersion of the powder agglomerates, the suspension was stirred using a magnetic stirrer for over $12 \mathrm{~h}$ at room temperature. Degassing of the suspension was achieved in a bell jar connected to a vacuum pump. A colloidal consolidation technique employing a gypsum mold was used to consolidate the colloidal particles. The compacts were then dried overnight at $100^{\circ} \mathrm{C}$.

Thermogravimetric analysis (TGA; TGA7 thermogravimetric analyzer, Perkin-Elmer, Norwalk, CT) was conducted to determine the oxidation level of $\mathrm{SiC}$ by weight increase. The dried compacts were put into a platinum pan and heated to predetermined soak temperatures at a heating rate of $10^{\circ} \mathrm{C} / \mathrm{min}$ in a stream of air.

After partial oxidation treatment in air, reaction sintering was conducted in an alumina crucible in a stream of Ar using a graphite furnace at a heating rate of $25^{\circ} \mathrm{C} / \mathrm{min}$ and a cooling rate of $5^{\circ} \mathrm{C} / \mathrm{min}$. The densities of the green compacts and the sintered bodies were measured by the Archimedes method using kerosene or distilled water, respectively. The pore channel size distribution of the compacts was determined by mercury porosimetry. ${ }^{1,12}$ The pore channel size distribution was obtained using standard values for the mercury surface energy $(0.48$ $\mathrm{N} / \mathrm{m})$ and the contact angle $\left(140^{\circ}\right)$. Phase analysis was conducted by X-ray diffraction (XRD; X-ray diffractometer, Philips Electronic Instruments, Inc, Mahwah, NJ) using Ni-filtered $\mathrm{Cu} K \alpha$ radiation. Sintered samples were polished down to a $1-\mu \mathrm{m}$ surface finish with diamond paste and then thermally etched at $1450^{\circ} \mathrm{C}$ for $20 \mathrm{~min}$ in an $\mathrm{Ar}$ atmosphere. The resulting microstructures were evaluated by scanning electron microscopy (SEM; Philips 515 scanning electron microscope) and transmission electron microscopy (TEM; Philips 300 transmission electron microscope).

\section{Results and Discussion}

\section{(1) Consolidation Process}

In preparing colloidal suspensions, controlling the interactions between particles has a significant influence on the stability of a suspension. In our system, an electrosteric stabilization approach was preferred over an electrostatic one since it was not possible to disperse both $\mathrm{SiC}$ and $\mathrm{Al}_{2} \mathrm{O}_{3}$ equally well at the same $\mathrm{pH}$ level. When only electrostatic dispersion was used, $\mathrm{SiC}$ dispersed best under basic conditions since the zeta potential is higher in basic solutions, as seen in Fig. 3, whereas $\mathrm{Al}_{2} \mathrm{O}_{3}$ dispersed best under acidic conditions. ${ }^{13-15}$ Consequently, an $\mathrm{NH}_{4}$ salt of PMAA was used as an electrosteric stabilizer $(0.4$ $\left.\mathrm{g} / \mathrm{m}^{2}\right)^{14,15}$ to improve the stability of $\mathrm{Al}_{2} \mathrm{O}_{3}$ under basic conditions so that a low-viscosity composite suspension could be prepared at $\mathrm{pH} 10$.

Figure 4 shows pore channel size distributions of the $\mathrm{Al}_{2} \mathrm{O}_{3}-$ $15 \mathrm{SiC}(\mathrm{C})$ compacts consolidated by the colloidal consolidation of the suspensions with different values of $\mathrm{pH}$. A green compact with a narrow pore channel size distribution with small pores could be obtained by adjusting the $\mathrm{pH}$.

During colloidal consolidation of binary suspensions, a key problem is the segregation of particles due to either gravitationa $1^{11,12,16}$ or thermodynamic phase separation ${ }^{17,18}$ effects. The best solution for minimizing particle segregation is to prepare the suspensions as highly concentrated as possible. ${ }^{11,12,16-19} \mathrm{In}$ our system, to check if segregation and/or phase separation occurred, the green densities and $\mathrm{X}$-ray intensity ratios along the perpendicular axis of both $\mathrm{Al}_{2} \mathrm{O}_{3}-15 \mathrm{SiC}(\mathrm{C})$ and $\mathrm{Al}_{2} \mathrm{O}_{3}-$ $15 \mathrm{SiC}(\mathrm{F})$ compacts (approximately $3.5 \mathrm{~cm}$ height) were measured. Because these displayed similar values within experimental error, it was concluded that significant segregation and/or phase separation did not occur while using a 45 vol\% solid suspension. As shown in Figs. 5 and 6, relatively

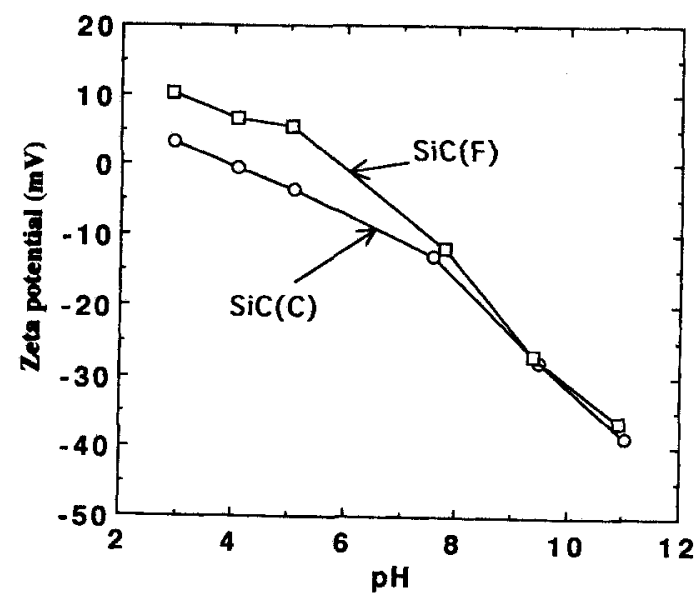

Fig. 3. Plots of zeta potential vs $\mathrm{pH}$ for $\mathrm{SiC}(\mathrm{C})$ and $\mathrm{SiC}(\mathrm{F})$. 


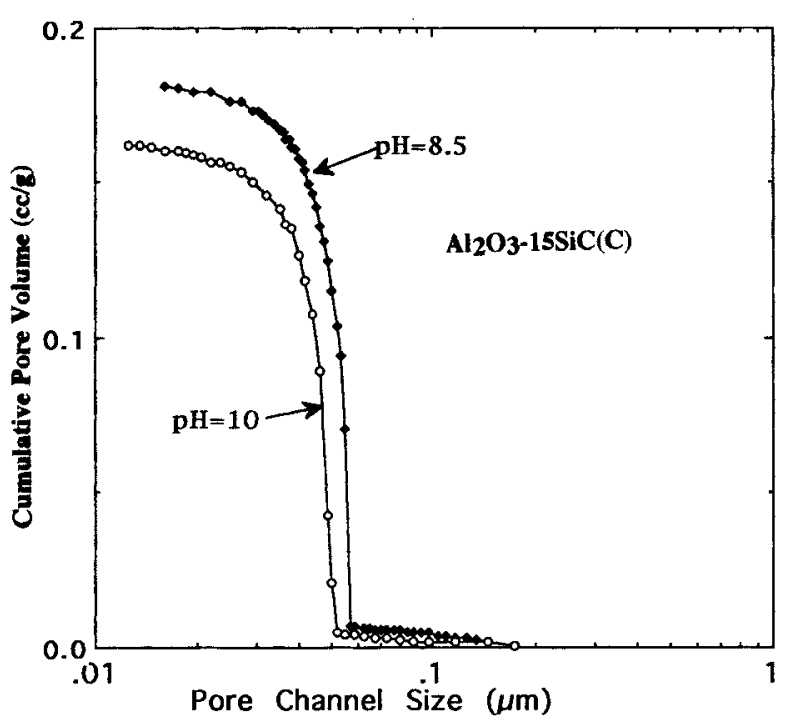

Fig. 4. Pore channel size distributions of the $\mathrm{Al}_{2} \mathrm{O}_{3}-15 \mathrm{SiC}(\mathrm{C})$ compacts consolidated by the colloidal consolidation of the suspensions with different values of $\mathrm{pH}$.

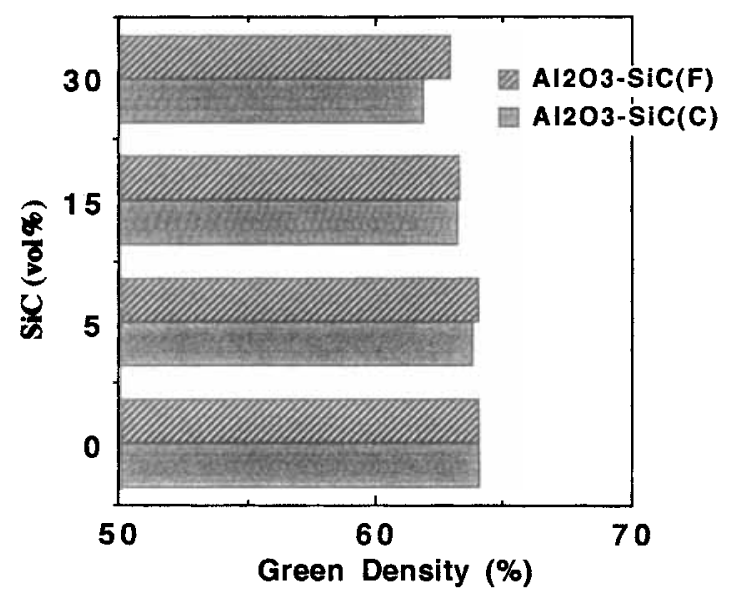

Fig. 5. Green densities of the colloidally consolidated composites with various amounts of $\mathrm{SiC}(\mathrm{C})$ and $\mathrm{SiC}(\mathrm{F})$ powders.

high green densities (Fig. 5) and narrow pore channel size distributions (Fig. 6) obtained with all of these compacts were also an indication of the consolidation of the particles without significant segregation.

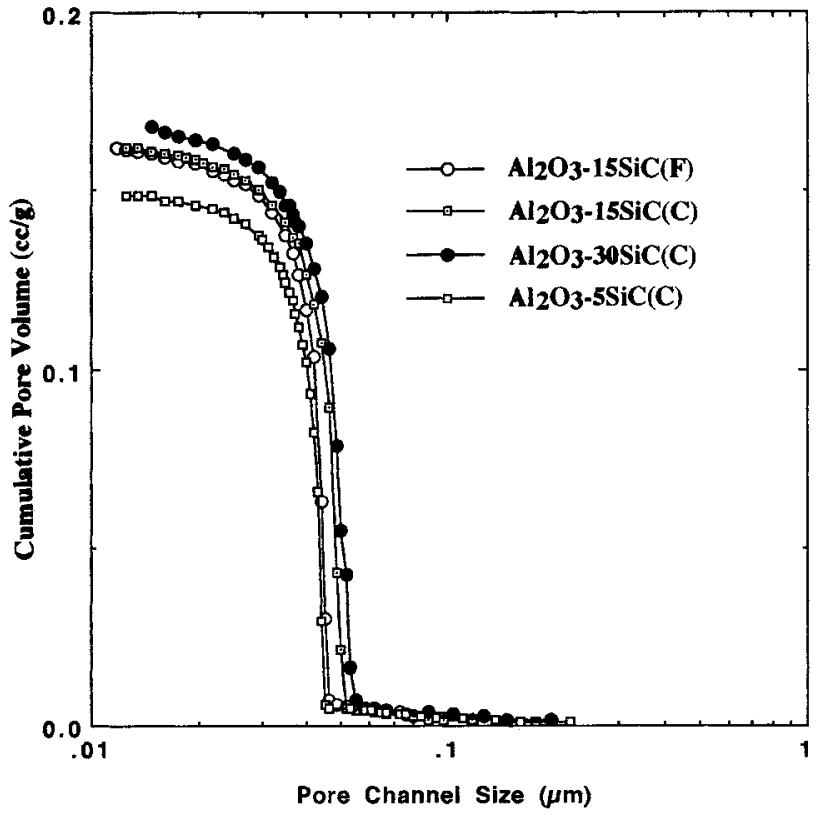

Fig. 6. Pore channel size distributions of the colloidally consolidated composites with various amounts of $\mathrm{SiC}(\mathrm{C})$ and $\mathrm{SiC}(\mathrm{F})$ powders.

\section{(2) Oxidation Process}

The typical weight losses and/or gains when heating $\mathrm{Al}_{2} \mathrm{O}_{3}-$ $15 \mathrm{SiC}(\mathrm{F})$ and $\mathrm{Al}_{2} \mathrm{O}_{3}-15 \mathrm{SiC}(\mathrm{C})$ at a heating rate of $10^{\circ} \mathrm{C} / \mathrm{min}$ are shown in Fig. 7. Upon heating to $700^{\circ} \mathrm{C}$ weight loss was observed in three regions for the $\mathrm{Al}_{2} \mathrm{O}_{3}-15 \mathrm{SiC}(\mathrm{C})$ sample: in the first region (up to $300^{\circ} \mathrm{C}$ ), the second (around $350^{\circ} \mathrm{C}$ ), and the third (around $650^{\circ} \mathrm{C}$ ). To determine the origin of the weight loss, a TGA experiment on the $\mathrm{Al}_{2} \mathrm{O}_{3}$ compact after colloidal consolidation was conducted. By comparison with the weight loss of $\mathrm{Al}_{2} \mathrm{O}_{3}-15 \mathrm{SiC}(\mathrm{C})$ and $\mathrm{Al}_{2} \mathrm{O}_{3}$, it is concluded that the first weight loss was due to desorption of water and the second is due to decomposition of the surfactant. Although slight weight loss of $\mathrm{Al}_{2} \mathrm{O}_{3}$ was observed due to the chemically bonded water (i.e., hydroxy groups) in the temperature range of 400 $1000^{\circ} \mathrm{C}$, the weight loss was different from that of the third region. Temperature-programmed desorption measurement ${ }^{20,21}$ of $\mathrm{SiC}(\mathrm{C})$ powder in oxygen atmosphere was conducted, where the evolved gases were monitored with a quadrupole spectrometer. The evolution of $\mathrm{CO}$ and $\mathrm{CO}_{2}$ was observed in the third region. Therefore, in the third region the weight loss was mainly due to the evolution of carbon oxide from carbon impurity. In the case of $\mathrm{Al}_{2} \mathrm{O}_{3}-15 \mathrm{SiC}(\mathrm{F})$, the third region was not observed because carbon was not a major impurity in the $\mathrm{SiC}(\mathrm{F})$. Above $700^{\circ} \mathrm{C}$ for $\mathrm{Al}_{2} \mathrm{O}_{3}-15 \mathrm{SiC}(\mathrm{C})$ and above $500^{\circ} \mathrm{C}$ for $\mathrm{Al}_{2} \mathrm{O}_{3}-15 \mathrm{SiC}(\mathrm{F})$, the weight loss reached a maximum value

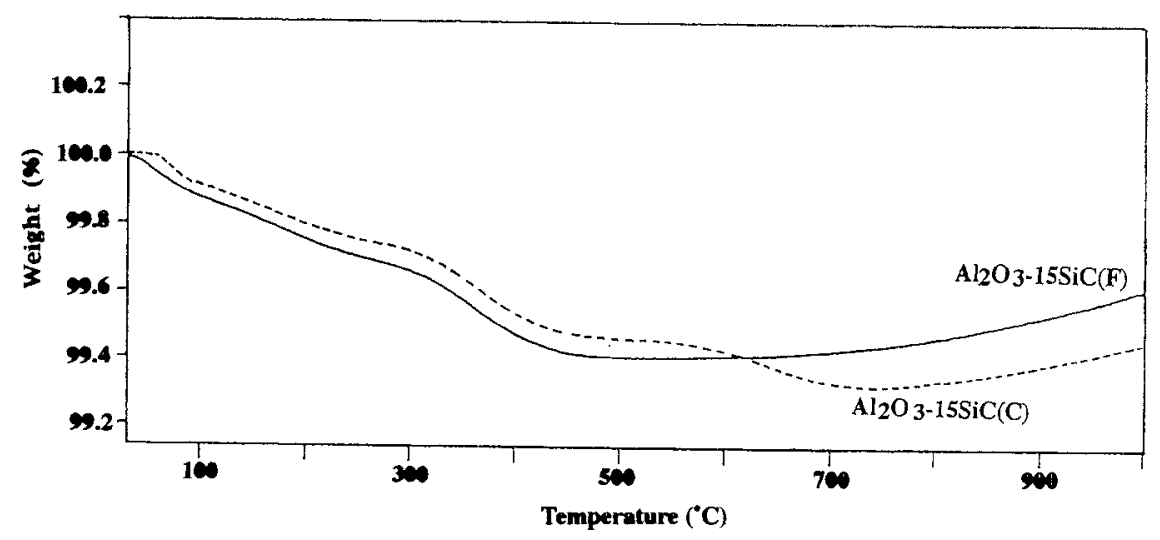

Fig. 7. TGA curves of colloidal consolidated compacts of $\mathrm{Al}_{2} \mathrm{O}_{3}-15 \mathrm{SiC}(\mathrm{C})$ and $\mathrm{Al}_{2} \mathrm{O}_{3}-15 \mathrm{SiC}(\mathrm{F})$ at a heating rate of $10^{\circ} \mathrm{C} / \mathrm{min}$ in a stream of air. 
and, because of the onset of $\mathrm{SiC}$ oxidation, a weight gain was observed at higher temperatures. The plateau value at the maximum weight loss was used as the reference point to approximate the fraction of silica that formed as an oxidation product on the surface of the SiC particles.

The size of the SiC core particles was controlled by determining the fraction of $\mathrm{SiC}$ oxidized during heat treatment. Figure 8 shows the weight gain and oxidation fraction. Because of its finer particle size, the oxidation fraction of the $\mathrm{SiC}(\mathrm{F})$ system is higher than that of the $\mathrm{SiC}(\mathrm{C})$ system. The oxidation behavior of $\mathrm{SiC}$ powder in this temperature range is believed to be the following passive oxidation reaction: ${ }^{22}$

$$
\mathrm{SiC}+2 \mathrm{O}_{2} \rightarrow \mathrm{SiO}_{2}+\mathrm{CO}_{2}
$$

The oxidation reactions at $1400^{\circ} \mathrm{C}$ are depressed by comparison

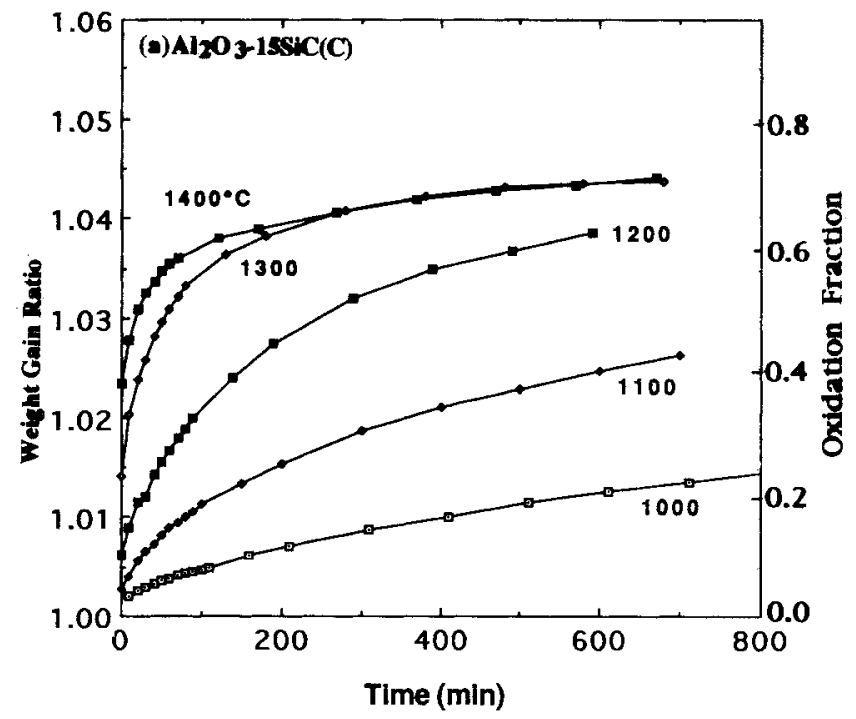

(a) with those at $1300^{\circ} \mathrm{C}$, especially for the $\mathrm{SiC}(\mathrm{C})$ system, as seen in Fig. 8. This phenomenon may be due to the significant sintering occurring simultaneously with the oxidation reaction at $1400^{\circ} \mathrm{C}$. Therefore, partial oxidation treatments were conducted below $1400^{\circ} \mathrm{C}$. Many authors have reported that oxidation of $\mathrm{SiC}$ powders in various oxidizing atmospheres follows parabolic reaction rate kinetics. ${ }^{22-27}$ The oxidation fraction can be represented by the following Jander's equation: ${ }^{28}$

$$
1-(1-f)^{1 / 3}=(k t)^{1 / 2}
$$

where $f$ is the oxidation fraction, $t$ is the reaction time, and $k$ is the rate constant. As shown in Fig. 9, when $1-(1-f)^{1 / 3}$ is plotted versus the square root of time, a linear variation is observed at low temperatures $\left(1000-1200^{\circ} \mathrm{C}\right)$ and also within the initial stages of higher temperature oxidation treatments,

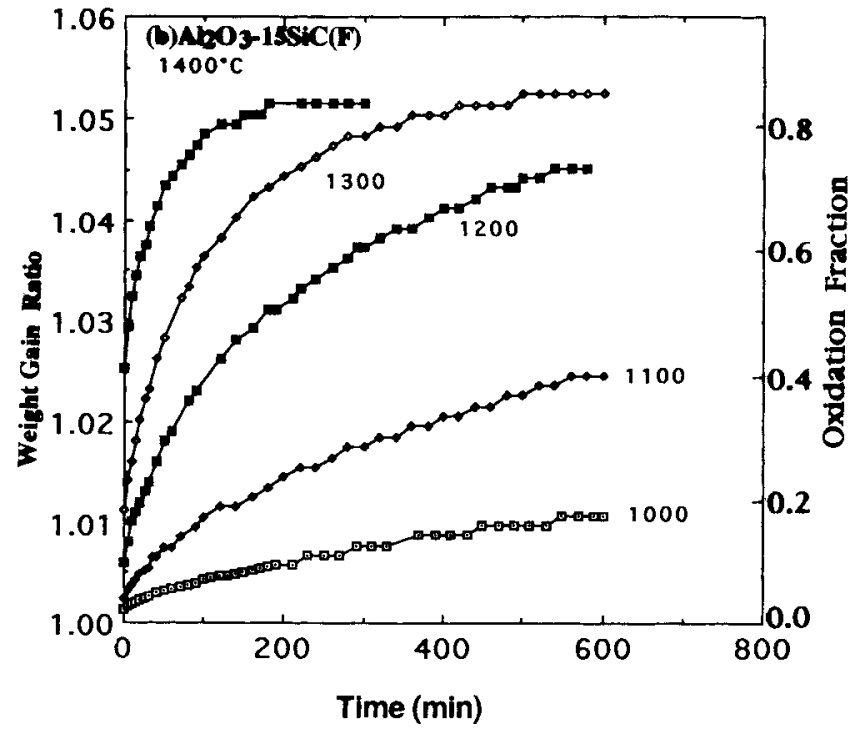

(b)

Fig. 8. Weight increase ratio (left-hand side) and oxidation fraction (right-hand side) of (a) $\mathrm{Al}_{2} \mathrm{O}_{3}-15 \mathrm{SiC}(\mathrm{C})$ and (b) $\mathrm{Al} \mathrm{O}_{3}-15 \mathrm{SiC}(\mathrm{F})$ composites during isothermal holding in a stream of air.

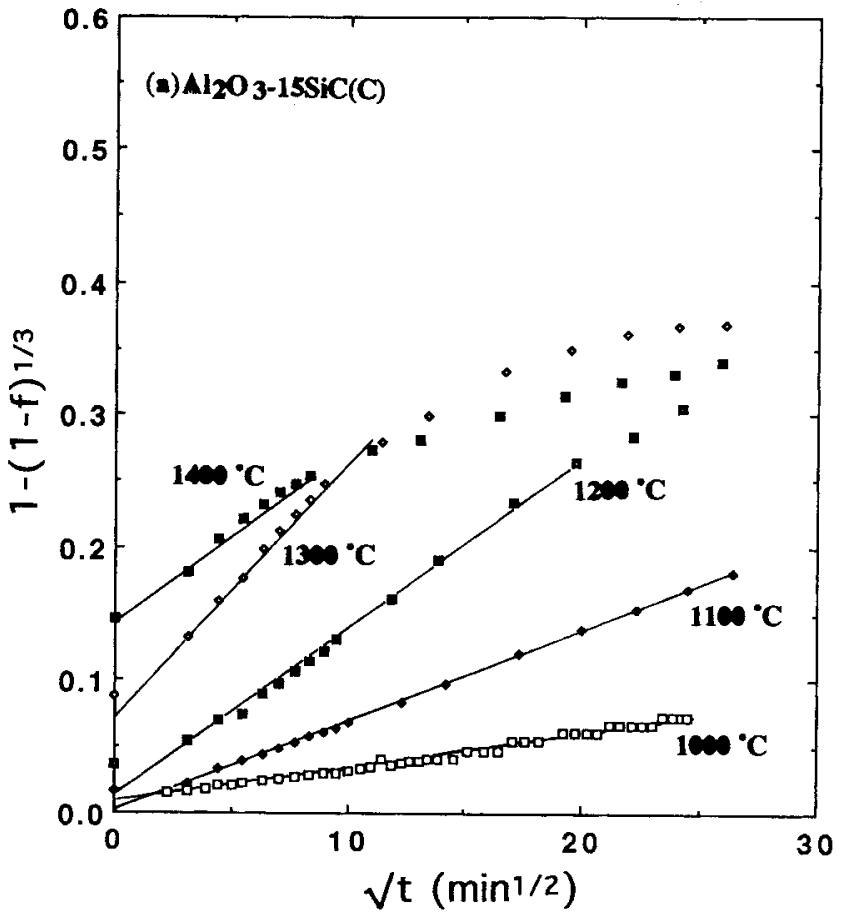

(a)

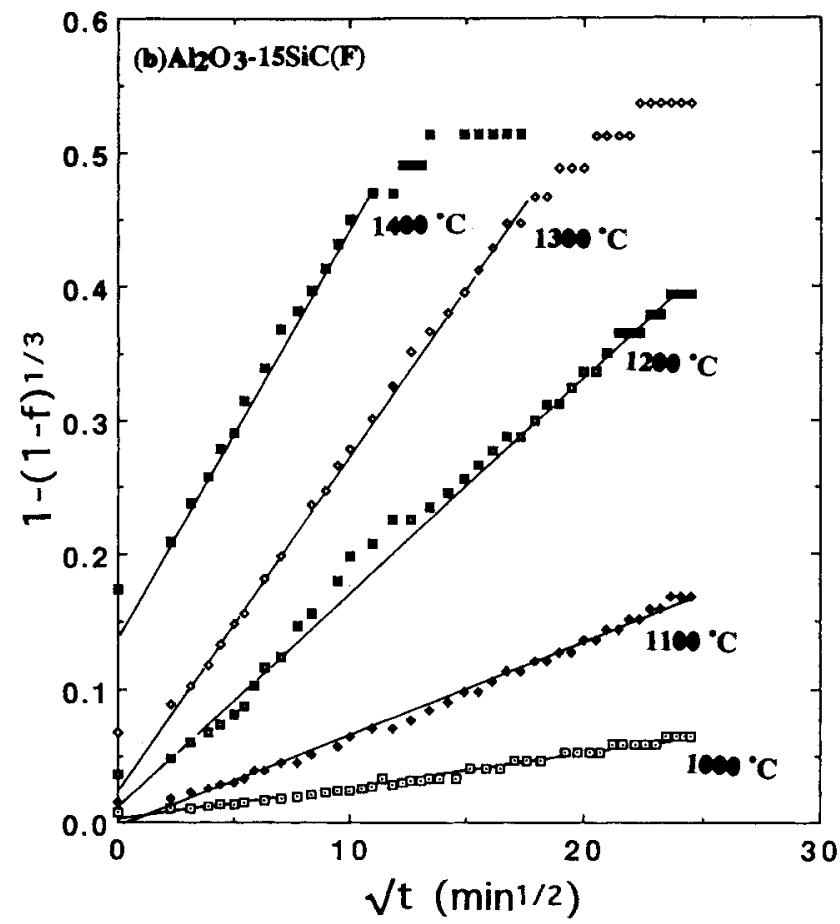

(b)

Fig. 9. Relationship between square root of time and $1-(1-f)^{1 / 3}$ for (a) $\mathrm{Al}_{2} \mathrm{O}_{3}-15 \mathrm{SiC}(\mathrm{C})$ and (b) $\mathrm{Al}_{2} \mathrm{O}_{3}-15 \mathrm{SiC}(\mathrm{F})$ composites during isothermal holding in a stream of air. 
suggesting that oxidation is rate limited by a diffusion process. Using Eq. (2), we can calculate the rate constants at every temperature. Arrhenius plots of the rate constants in the temperature range of $1000-1300^{\circ} \mathrm{C}$ are shown in Fig. 10. The activation energies of $\mathrm{Al}_{2} \mathrm{O}_{3}-\mathrm{SiC}(\mathrm{F})$ and $\mathrm{Al}_{2} \mathrm{O}_{3}-15 \mathrm{SiC}(\mathrm{C})$ are 256 and 216 $\mathrm{kJ} / \mathrm{mol}$, respectively. Activation energies reported in the literature vary from 134 to $498 \mathrm{~kJ} / \mathrm{mol}^{22-27}$ The large amount of scatter has been attributed to the different types of materials (powder, polycrystal, and single crystal) with varying concentrations of impurities, which can alter the oxidation kinetics significantly. In our case, the activation energies are close to the activation energy of the ionic oxygen diffusion in vitreous silica $(298 \mathrm{~kJ} / \mathrm{mol})^{29}$ but not to that of the molecular oxygen diffusion $(113 \mathrm{~kJ} / \mathrm{mol}) .^{30}$ Therefore, the present oxidation reaction seems to proceed via ionic oxygen diffusion through a silica film.

Figure 11 shows the X-ray diffraction patterns of $\mathrm{Al}_{2} \mathrm{O}_{3}-$ $15 \mathrm{SiC}$ oxidized at $1300^{\circ} \mathrm{C}$ for $5 \mathrm{~h}$ in air. The decrease in the amount of $\mathrm{SiC}$ and the gain in the amount of $\mathrm{SiO}_{2}$ (cristobalite and amorphous phase) can be seen from the figure. In the case of $\mathrm{Al}_{2} \mathrm{O}_{3}-15 \mathrm{SiC}(\mathrm{F})$ (Fig. 11(b)), the $\mathrm{SiC}$ peak was broader and

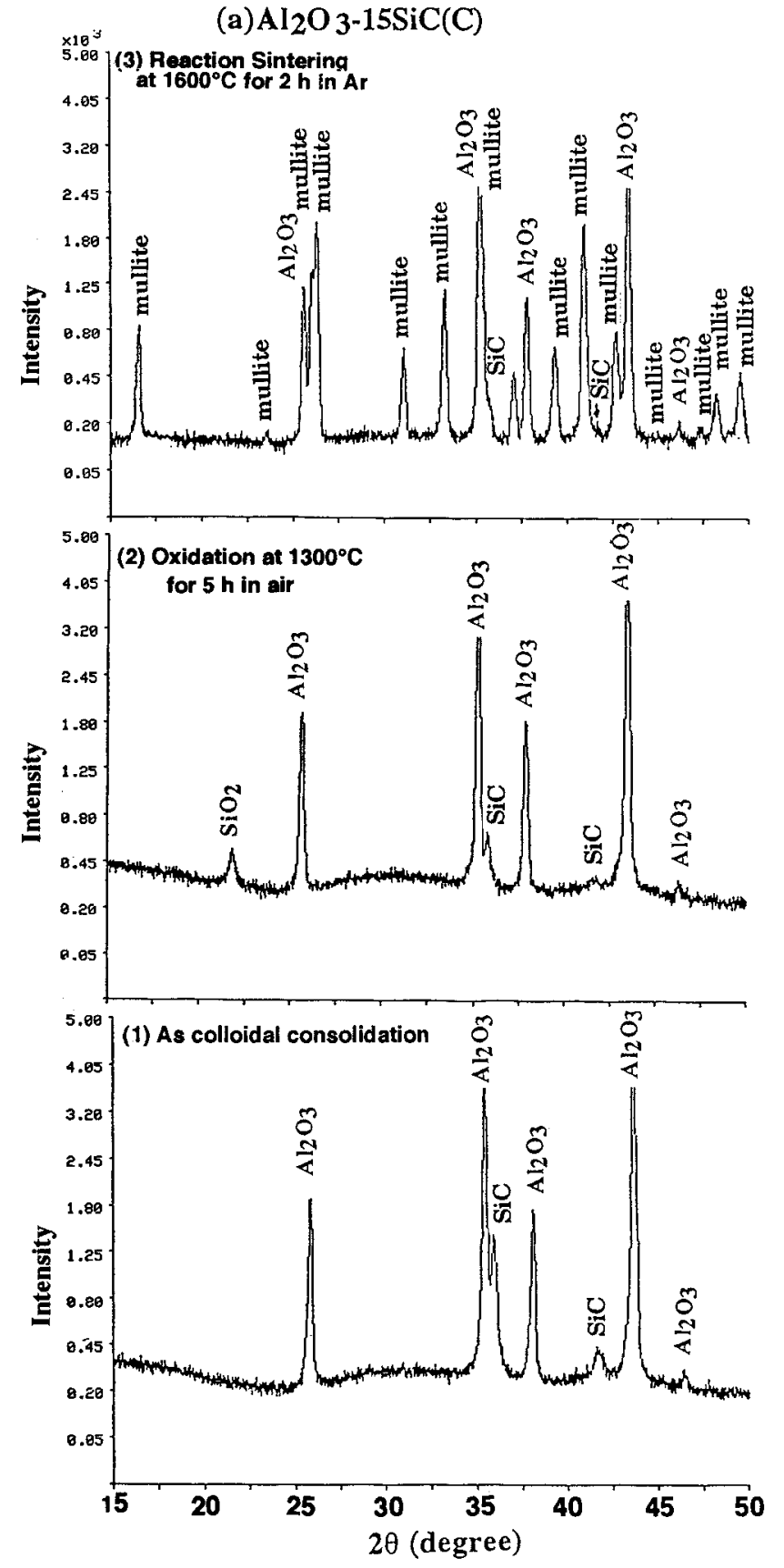

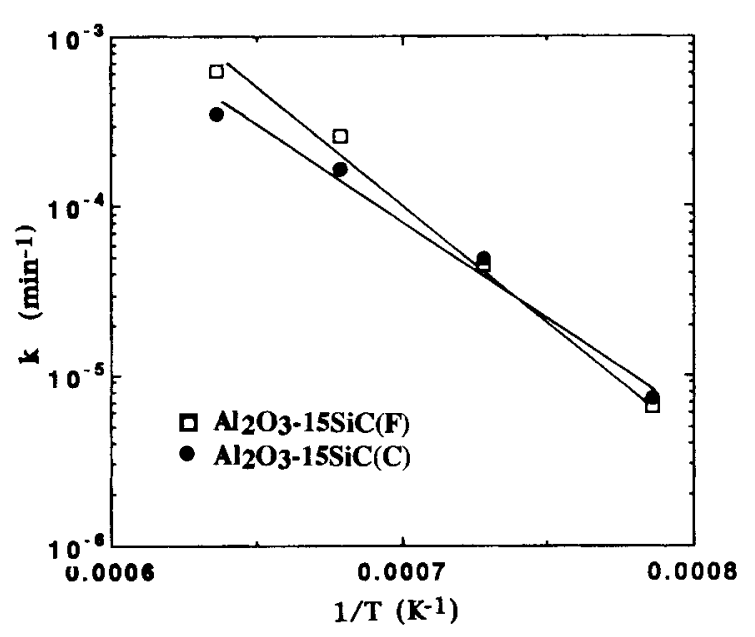

Fig. 10. Arrhenius plots of the rate constants.

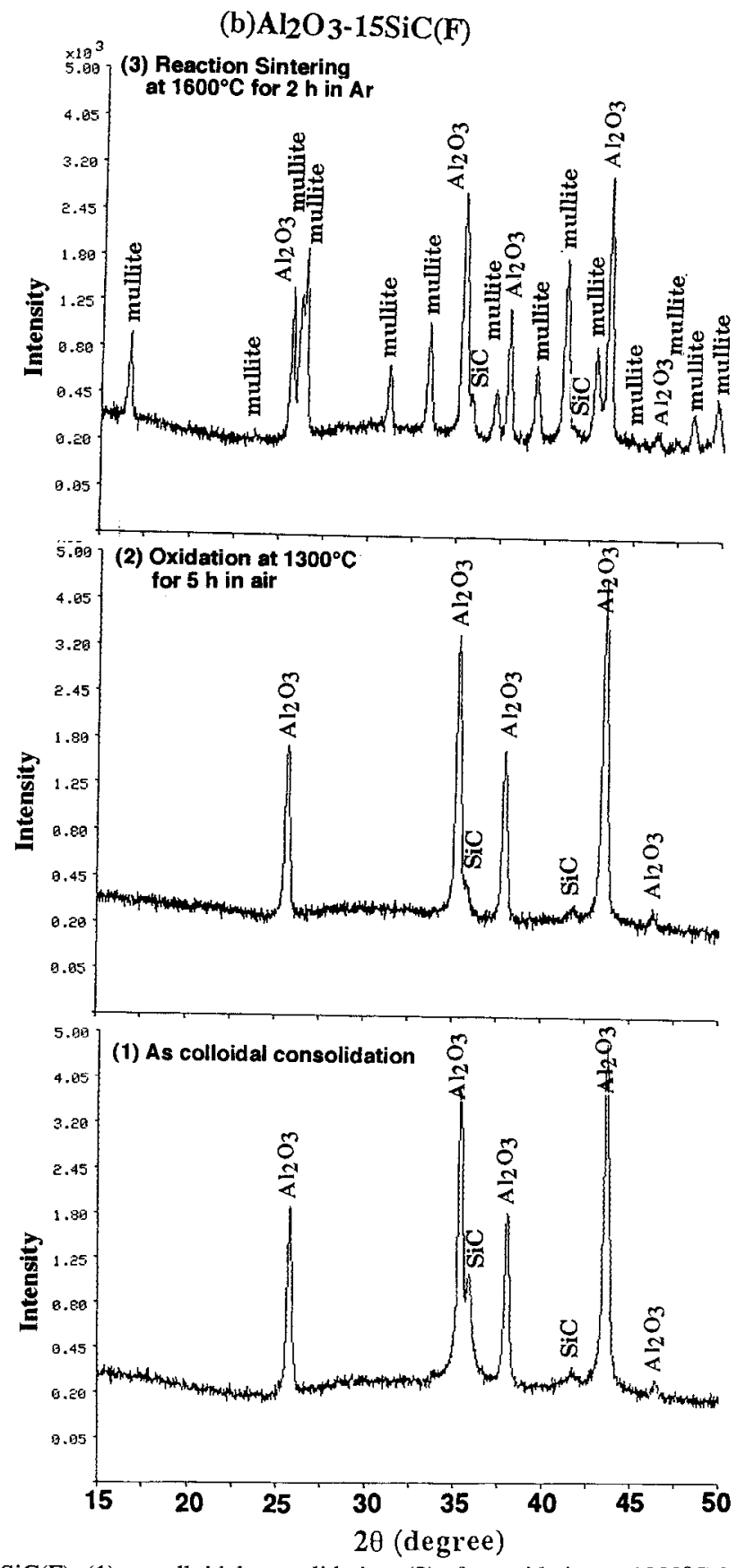

Fig. 11. X-ray diffraction patterns of (a) $\mathrm{Al}_{2} \mathrm{O}_{3}-15 \mathrm{SiC}(\mathrm{C})$ and (b) $\mathrm{Al}_{2} \mathrm{O}_{3}-15 \mathrm{SiC}(\mathrm{F})$ : (1) as colloidal consolidation, (2) after oxidation at $1300^{\circ} \mathrm{C}$ for $5 \mathrm{~h}$ in air, and (3) after reaction sintering at $1600^{\circ} \mathrm{C}$ for $2 \mathrm{~h}$ in Ar. 
the cristobalite phase was not observed after partial oxidation treatment. It is important to note that a large quantity of cristobalite is not preferred since cristobalite causes micro- and macrocracking during its $\beta$ - to $\alpha$-cristobalite polymorphic phase transformation during cooling.

\section{(3) Reaction Sintering and Microstructure}

Comparison of the X-ray diffraction patterns in Fig. 11 confirms the premise of this study that the $\mathrm{SiO}_{2}$ phase would form as an oxidation product and be consumed to form mullite during the final stage heat treatment in Ar. In calculating the theoretical densities of the compacts, two types of volume expansion had to be considered. ${ }^{31}$ Volume expansion of $\mathrm{SiC}$ upon oxidation is $107 \%$ and formation of stoichiometric mullite from the reaction of $3 \mathrm{Al}_{2} \mathrm{O}_{3}$ and $2 \mathrm{SiO}_{2}$ results in a volume increase of $\sim 5 \%$ assuming that the densities of $\mathrm{Al}_{2} \mathrm{O}_{3}, \mathrm{SiO}_{2}$, and mullite are 3.99, 2.33 , and $3.16 \mathrm{~g} / \mathrm{cm}^{3}$, respectively. The theoretical densities were determined by the following equation:

$$
\rho=\left[V_{\mathrm{s}} \rho_{\mathrm{s}}+\left(1-V_{\mathrm{s}}\right) \rho_{\mathrm{A}}\right] W / k
$$

where $\rho_{\mathrm{s}}$ and $\rho_{\mathrm{A}}$ are the theoretical densities of $\mathrm{SiC}$ and $\mathrm{Al}_{2} \mathrm{O}_{3}$, respectively, $V_{\mathrm{s}}$ is the volume fraction of $\mathrm{SiC}$, and $W$ is the oxidation weight increase ratio. $k$ is a factor controlled by the composition and the respective volume expansions:

$$
k=\frac{f V_{\mathrm{s}}(2.07 \times 1.05-1)}{1+(1-f) V_{\mathrm{s}}}+1
$$

where $f$ is the oxidation fraction of $\mathrm{SiC}$.

The effects of the oxidation conditions on the sintered densities are shown in Fig. 12. Note that when the oxidation fraction exceeded $40 \%$ (by comparison of Figs. 8 and 12), sintered densities above $95 \%$ were obtained by sintering at $1600^{\circ} \mathrm{C}$ for $2 \mathrm{~h}$ in an Ar atmosphere. In contrast, the densities of the samples with no partial oxidation treatment were very low. The presence of amorphous silica after surface oxidation of $\mathrm{SiC}$ accelerates the

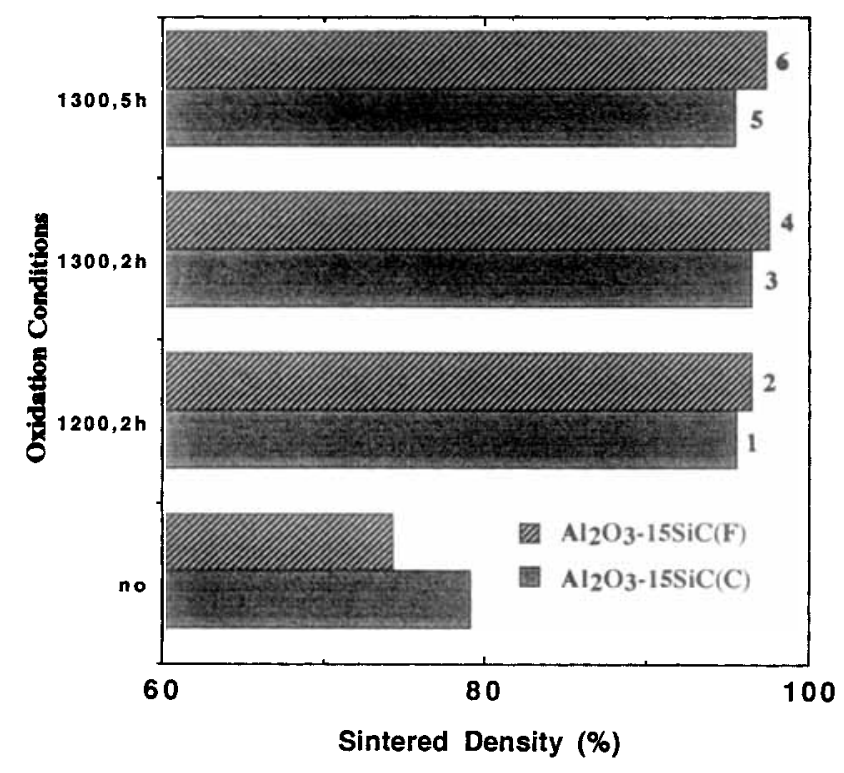

Fig. 12. Effect of oxidation conditions on the densities of the compacts sintered at $1600^{\circ} \mathrm{C}$ for $2 \mathrm{~h}$ in Ar. Calculated compositions of the produced nanocomposites are as follows:

\begin{tabular}{cccc}
\hline & \multicolumn{3}{c}{ Composition (vol\%) } \\
\cline { 2 - 4 } Sample no. & $\mathrm{Al}_{2} \mathrm{O}_{3}$ & Mutlite & $\mathrm{SiC}$ \\
\hline 1 & 63.5 & 27.6 & 8.9 \\
2 & 61.0 & 31.0 & 8.0 \\
3 & 52.3 & 42.1 & 5.6 \\
4 & 51.3 & 43.5 & 5.2 \\
5 & 48.2 & 47.3 & 4.5 \\
6 & 43.5 & 53.6 & 2.9 \\
\hline
\end{tabular}

sintering significantly. A possible explanation for this is the lowering of porosity due to volume expansion during the oxidation of SiC. Although amorphous silica forms only on the $\mathrm{SiC}$ particles, the possibility of enhanced densification due to its transient presence needs further investigation. ${ }^{32,33}$ As expected, the final composite densities show a slight decrease as the initial $\mathrm{SiC}$ content is increased (Fig. 13).

Figure 14 shows a SEM micrograph of a polished and etched $\mathrm{Al}_{2} \mathrm{O}_{3}-15 \mathrm{SiC}(\mathrm{C})$ sample that was oxidized at $1300^{\circ} \mathrm{C}$ and sintered at $1600^{\circ} \mathrm{C}$. At this resolution, although small secondphase inclusions are observed, it is not obvious whether these inclusions extend to the nanoscale range. In TEM characterization of the composites, two types of nanoscale inclusions were observed (Fig. 15). In the first type (Fig. 15(a)), nanometersized $\mathrm{SiC}$ particles were observed as inclusions within a mullite matrix as confirmed by energy dispersive X-ray spectroscopy (EDS), where the SiC particles were seen as dark spots. In the second type (Fig. 15(b)), mullite whiskers were observed within the SiC grains, again as confirmed by EDS analysis.

These morphologies are explained as follows. When Mitsui Toatsu's fine $\mathrm{SiC}$ is used, the surface of the SiC is oxidized uniformly and nanometer-sized SiC particles remain in the mullite matrix as illustrated in Figs. 1 and 15(a). In contrast, since Superior Graphite's SiC powders are coarser and are produced by milling, the powders may have grain boundaries and cracks

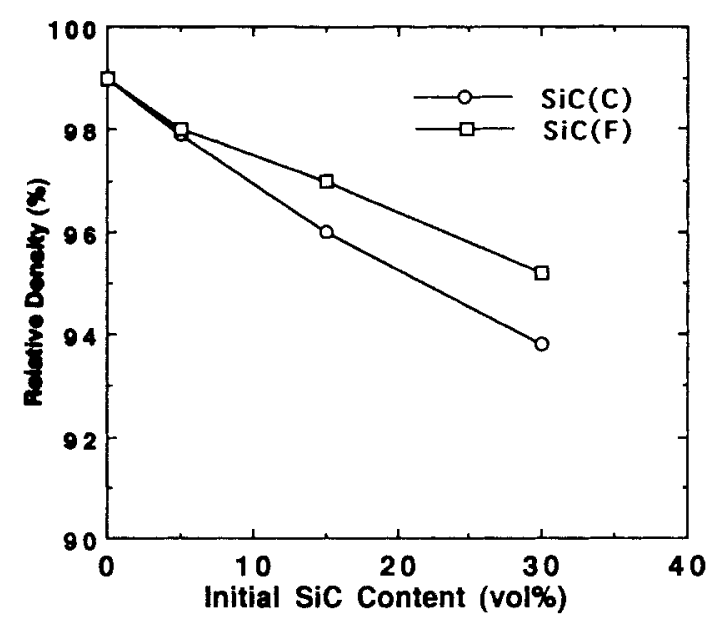

Fig. 13. Effect of initial $\mathrm{SiC}$ contents on density after an initial oxidation at $1300^{\circ} \mathrm{C}$ in air and then a final sintering at $1600^{\circ} \mathrm{C}$ for $2 \mathrm{~h}$ in Ar.

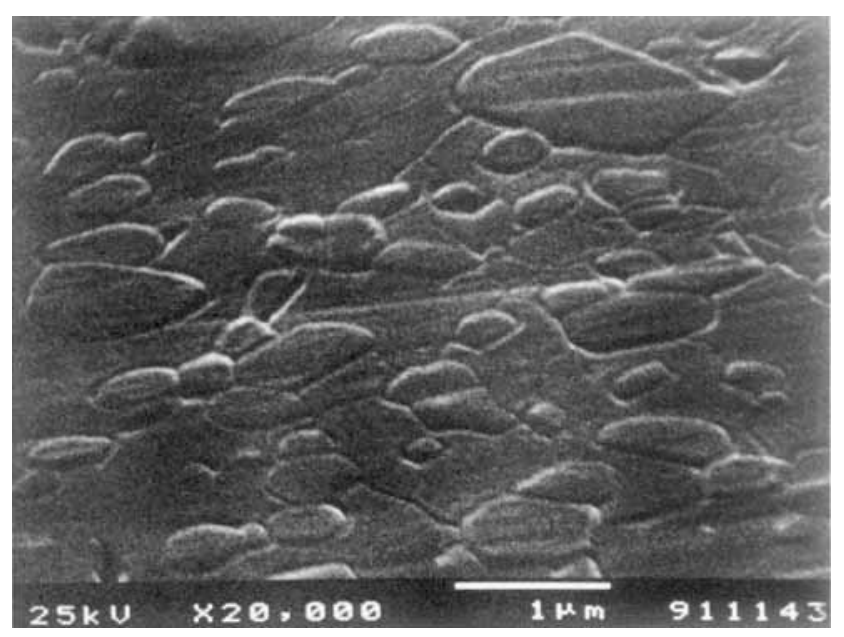

Fig. 14. SEM micrograph of polished and thermally etched $\mathrm{Al}_{2} \mathrm{O}_{3}-$ $15 \mathrm{SiC}(\mathrm{C})$ composite first oxidized at $1300^{\circ} \mathrm{C}$ for $5 \mathrm{~h}$ and followed by a $1600^{\circ} \mathrm{C}$ sintering for $2 \mathrm{~h}$ in $\mathrm{Ar}$. 

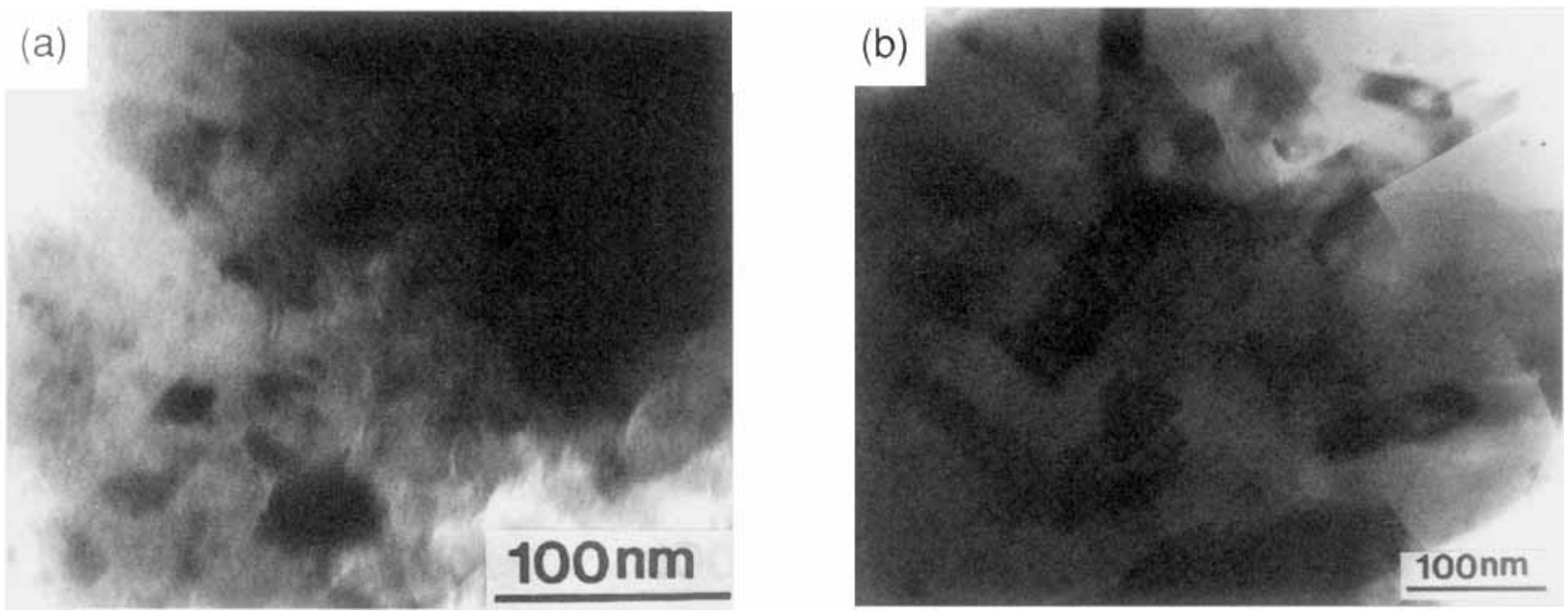

Fig. 15. TEM micrographs of (a) $\mathrm{Al}_{2} \mathrm{O}_{3}-15 \mathrm{SiC}(\mathrm{F})$ and (b) $\mathrm{Al}_{2} \mathrm{O}_{3}-15 \mathrm{SiC}(\mathrm{C})$ composites first oxidized at $1300^{\circ} \mathrm{C}$ for $5 \mathrm{~h}$ in air and followed by a final sintering treatment at $1600^{\circ} \mathrm{C}$ for $2 \mathrm{~h}$ in Ar.

that result in preferential oxidation into the $\mathrm{SiC}$ grains, producing the type of microstructure observed in Fig. 15(b) by the mechanism summarized below.

Recent studies have shown that in the temperature range $<1500^{\circ} \mathrm{C}$, mullite forms by a nucleation and growth process within the silica-rich matrix (but not at the alumina interfaces) as the siliceous matrix is saturated with respect to mullite through the dissolution of alumina. ${ }^{34-36}$ In this process, first, $\mathrm{Al}_{2} \mathrm{O}_{3}$ dissolves into the amorphous silica matrix; second, mullite nuclei form within this matrix as the matrix composition exceeds the saturation limit with respect to mullite; and third, mullite crystals grow as more alumina dissolves into the matrix and then is incorporated into the growing mullite grains. The nucleation and growth of mullite within silica-rich fissures on the coarse SiC would then be consistent with the morphology observed in Fig. 15(b).

\section{Conclusions}

$\mathrm{SiC}-$ mullite- $\mathrm{Al}_{2} \mathrm{O}_{3}$ nanocomposites were processed through a novel colloidal consolidation and reaction sintering process. First, micrometer-sized $\mathrm{SiC}$ and $\mathrm{Al}_{2} \mathrm{O}_{3}$ particles were colloidally dispersed and consolidated to form uniformly mixed compacts. Second, the SiC particles were partially oxidized to reduce them to nanometer-sized cores. Third, these nanometersized core particles were trapped within a mullite matrix as the silica oxidation product reacted with alumina to form mullite.

This process offers several advantages and thereby warrants further research: (1) it eliminates the need to reduce the particle size of the inclusion phase to the nanometer range by milling and thus provides better control in minimizing impurities; and (2) because of a volume increase during reaction sintering, sintering shrinkages are lower.

Acknowledgments: The main part of this work was conducted in the Department of Materials Science and Engineering, University of Washington, Seattle, WA. We acknowledge M. Sarikaya and J. Liu of the University of Washington, and T. Uchikoshi of NRIM, for their help with the TEM observations. We also wish to thank Otsuka Electrics and Bel Japan, Inc., for measuring the electrophoretic mobility.

\section{References}

'R. P. Andres, R. S. Averback, W. L. Brown, W. A. Goddard III, A. Kaldor, S. G. Louie, M. Moscovits, P. S. Peercy, S. J. Riley, R. W. Siegel, F. Spaepen, and Y. Wang, "Research Opportunities on Cluster and Cluster-Assembled Materials," J. Mater. Res. 4 [3] 705-36 (1989).

${ }^{2}$ R. W. Siegel, R. Ramasamy, H. Hahn, L. Tiang, and R. Gronsky, "Synthesis, Characterization, and Properties of Nanophase $\mathrm{TiO}_{2}$, " J. Mater. Res., 3, 1367$72(1988)$.

${ }^{3} \mathrm{~K}$. Niihara, "New Design Concepts of Structural Ceramics-Ceramic Nanocomposite," J. Ceram. Soc. Jpn., 99 [10] 974-82 (1991).
${ }^{4} \mathrm{H}$. Takada, A. Nakahira, H. Ohnishi, S. Ueda, and K. Niihara, "Improvement of Mechanical Properties of Natural Mullite/SiC Nanocomposite," Jpn. J. Powder Powder Met., 38, 348-51 (1991).

${ }^{5}$ T. N. Tiegs, P. F. Becher, and P. Angelini, "Microstructure and Properties of SiC Whisker-Reinforced Mullite Composite"; pp. 463-72 in Ceramic Transactions, Vol. 6, Mullite and Mullite Matrix Composites. Edited by S. Somiya, R. F. Davis, and J. A. Pask. American Ceramic Society, Westerville, OH, 1990.

${ }^{6}$ B. R. Marple and D. J. Green, "Mullite/Alumina Particulate Composites by Infiltration Processing: III, Mechanical Properties," J. Am. Ceram. Soc., 74 [10] 2453-59 (1991).

${ }^{7}$ Y. Sakka, D. D. Bidinger, J. Liu, M. Sarikaya, and I. A. Aksay, "Processing of SiC-Mullite- $\mathrm{Al}_{2} \mathrm{O}_{3}$ Nanocomposite"; pp. 15-26 in NASA Conference Publication, Vol. 3175, The 16th Conference on Metal Matrix, Carbon, and Ceramic Matrix Composites. Edited by J. D. Buckley. National Aeronautics and Space Administration, Washington, DC, 1992.

${ }^{8}$ I. A. Aksay, F. F. Lange, and B. I. Davis, "Uniformity of $\mathrm{Al}_{2} \mathrm{O}_{3}-\mathrm{ZrO}_{2}$ Composites by Colloidal Filtration," J. Am. Ceram. Soc., 60 [10] C-190-C-192 (1983).

${ }^{9}$ F. F. Lange, "Powder Processing Science and Technology for Increased Reliability," J. Am. Ceram. Soc., 72 [1] 3-15 (1989).

${ }^{10} \mathrm{~S}$. Ross and I. D. Morrion, Colloidal Systems and Interfaces; pp. 205-63. Wiley, New York, 1988

${ }^{11}$ C. Han, "Sintering of Bimodal Powder Compacts"; M.S. Thesis. University of California, Los Angeles, CA, 1985.

${ }^{12}$ C. Han, I. A. Aksay, and O. J. Whittemore, "Characterization of Microstructure Evolution with Mercury Porosimetry"; pp. 339-47 in Advances in Materials Characterization, $I$. Edited by R. L. Snyder, R. A. Condrate, Sr., and P. F. Johnson. Plenum, New York, 1985.

${ }^{13}$ E. Liden, L. Bergstrom, M. Persson, and R. Carlsson, "Surface Modification and Dispersion of Silicon Nitride and Silicon Carbide Powders," J. Eur. Ceram. Soc., 7 [6] 361-68 (1990).

${ }^{14}$ J. Cesarano III, I. A. Aksay, and A. Bleier, "Stability of Aqueous $\alpha-\mathrm{Al}_{2} \mathrm{O}_{3}$ Suspensions with Poly(methacrylic acid) Polyelectrolyte," J. Am. Ceram. Soc. 71 [4] 250-55 (1988).

${ }^{15} \mathrm{~J}$. Cesarano III and I. A. Aksay, "Processing of Highly Concentrated Aqueous $\alpha-\mathrm{Al}_{2} \mathrm{O}_{3}$ Suspensions Stabilized with Polyelectrolytes," J. Am. Ceram. Soc., 71 [12] 1062-67 (1988)

${ }^{6}$ Y. Hirata and I. A. Aksay, "Particle Segregation during Colloidal Filtration"; pp. 3-15 in Advances in Materials, Processing and Manufacturing, Proceedings of the Advanced Materials Technology Ceramic Workshop, No. 4. International Committee for Advanced Materials Technology, Nagoya, Japan, 1988.

${ }^{17}$ J. Liu, W. Y. Shih, R. Kikuchi, and I. A. Aksay, "Clustering of Binary Colloidal Suspensions: Theory," J. Colloid Interface Sci., 142 [2] 369-77 (1991).

${ }^{18}$ M. Yasrebi, W. Y. Shih, and I. A. Aksay, "Clustering of Binary Colloidal Suspensions: Experiment," J. Colloid Interface Sci., 142 [2] 357-68 (1991).

${ }^{19}$ M. D. Sacks and G. W. Scheiffele, "Properties of Silicon Suspensions and Slip-Cast Bodies," Ceram. Eng. Sci. Proc., 6 [7-8] 1109-23 (1985).

${ }^{20}$ Y. Sakka, T. Uchikoshi, and E. Ozawa, "Low-Temperature Sintering and Gas Desorption of Gold Ultrafine Powders," J. Less-Common Met., 147, 89-96 (1989).

${ }^{21}$ Y. Sakka, S. Ohno, and M. Uda, "Oxidation and Degradation of Titanium Nitride Ultrafine Powders Exposed to Air," J. Am. Ceram. Soc., 75 [1] 244-48 (1992).

${ }^{22}$ W. L. Vaughn and H. G. Maahs, "Active-to-Passive Transition in the Oxidation of Silicon Carbide and Silicon Nitride in Air," J. Am. Ceram. Soc., 73 [6] 1540-43 (1990)

${ }^{23}$ G. Ervin, Jr., "Oxidation Behavior of Silicon Carbide," J. Am. Ceram. Soc. 41 [9] 347-52 (1958)

${ }^{24}$ P. J. Jorgensen, M. E. Wadsworth, and I. B. Cutler, "Oxidation of Silicon Carbide," J. Am. Ceram. Soc., 42 [12] 613-16 (1959). 
${ }^{25} \mathrm{R}$. F. Adamsky, "Oxidation of Silicon Carbide in the Temperature Range 1200 to $1500^{\circ}$," J. Phys. Chem., 63, 305-7 (1959).

${ }^{26}$ K. L. Luthra, "Some New Perspectives on Oxidation of Silicon Carbide and Silicon Nitride," J. Am. Ceram. Soc., 74 [5] 1095-103 (1991).

${ }^{27}$ T. Shimoo, "Carbon Removal and Oxidation of SiC Powder Synthesized by Carbothermic Reduction of Silica," J. Ceram. Soc. Jpn., 99 [9] 768-73 (1991).

${ }^{28}$ W. Jander, "Reactions in Solid State at High Temperatures: I," Z. Anorg. Allg. Chem., 163, 1 (1927).

${ }^{29} \mathrm{E}$. W. Sucov, "Diffusion of Oxygen in Vitreous Silica," J. Am. Ceram. Soc, 46 [1] 14-20 (1963).

${ }^{30} \mathrm{~F}$. J. Norton, "Permeation of Gaseous Oxygen Through Vitreous Silica," Nature (London), 191, 4789 (1961).
${ }^{3} \mathrm{~S}$. Wu and N. Claussen, "Fabrication and Properties of Low-Shrinkage Reaction-Bonded Mullite," J. Am. Ceram. Soc, 74 (10] 2460-63 (1991).

${ }^{32}$ M. D. Sacks, N. Bozkurt, and G. W. Scheiffele, "Fabrication of MulliteMatrix Composites by Transient Viscous Sintering of Composite Powders," J. Am. Ceram. Soc., 74 [10] 2428-37 (1991).

${ }^{33} \mathrm{~J}$. E. Webb, "Processing Mullite for Use as a Ceramic-Ceramic Com" posite Matrix Material"; M.S. Thesis. University of Washington, Seattle, WA, 1991.

${ }^{34} \mathrm{~S}$. Sundaresan and I. A. Aksay, "Mullitization of Diphasic Aluminosilicate Gels," J. Am. Ceram. Soc., 74 [10] 2388--92 (1991).

${ }^{35}$ W. Wei and J. W. Halloran, "Transformation Kinetics of Diphasic Aluminosilicate Gels," J. Am. Ceram. Soc., 71 [7] 581-87 (1988).

${ }^{36}$ J. C. Huling and G. L. Messing, "Epitactic Nucleation of Spinel in Aluminosilicate Gels and Its Effect on Mullite Crystallization," J. Am. Ceram. Soc., 74 [10] 2374-81 (1991). 